\title{
Ectopic ureter associated with Zinner's syndrome in a kidney recipient: case report and literature review
}

\author{
Korhan Tuncer ${ }^{\mathbf{1}}$ \\ (iD) Gizem Kilinc ${ }^{1}$ \\ (iD) Ismail Sert ${ }^{\mathbf{1}}$ \\ Doksever Akpinar ${ }^{1}$ \\ (iD) Cem Tugmen ${ }^{1}$
}

1. Department of General Surgery, Tepecik Training and Research Hospital, Izmir, Turkey

http://dx.doi.org/10.1590/1806-9282.66.5.692

\section{SUMMARY}

INTRODUCTION: Zinner's Syndrome is a triad of mesonephric duct anomalies comprising unilateral renal agenesis, seminal vesicle cyst, and ejaculatory duct obstruction. In this study, we present a kidney recipient with ectopic ureter associated with Zinner's syndrome and a literature review.

CASE PRESENTATION: A 59-year-old male with a history of chronic kidney disease and left renal agenesis underwent deceased donor kidney transplantation. After securing optimal renal functions, the patient underwent abdominal computed tomography (CT) scan for the seroma that occurred under the incision. The final diagnosis was an ectopic distal ureter ending in the seminal vesicle cyst's wall and ipsilateral renal agenesis. The patient was discharged without any complications and the clinical follow up was uneventful.

DISCUSSION AND CONCLUSION: Congenital seminal vesicle disorders are usually associated with ipsilateral urinary duct anomalies stemming from the same embryonic structure. To our knowledge, this is the first case report that describes kidney transplantation in a patient with ipsilateral renal agenesis and ectopic ureter ending in the seminal vesicle cyst. In patients with renal agenesis, during the ipsilateral urinary tract anastomosis, the possibility of ectopic ureter should be kept in mind otherwise graft loss can occur with a high morbidity rate.

KEYWORDS: renal transplantation, seminal vesicle cyst, Zinner's syndrome

\section{INTRODUCTION}

Zinner's Syndrome is a triad of mesonephric duct anomalies comprising unilateral renal agenesis, seminal vesicle cyst, and ejaculatory duct obstruction. Congenital seminal vesicle disorders are usually associated with ipsilateral urinary duct anomalies consisting of the same embryonic structure, named mesonephric duct (Wolfian duct)' ${ }^{1}$. Ectopic ureter is described as a ureter opening to an area separate from the vesical trigone. Patients diagnosed with Zinner's Syndrome are usually asymptomatic, and symptomatic ones present prostatism, dysuria, and painful ejaculation. In this study, we present a kidney recipient with ectopic ureter associated with Zinner's syndrome and literature review. 


\section{CASE PRESENTATION}

A 59-year-old male with a history of chronic kidney disease and left renal agenesis underwent deceased donor kidney transplantation. Antithymocyte globulin (ATG) and corticosteroid were introduced as induction therapy; tacrolimus (FK506), mycophenolate mofetil, and corticosteroid were used as maintenance therapy. After securing the optimal renal functions, the patient underwent abdominal computed tomography (CT) scan for the seroma that occurred under the incision. Left renal agenesis and a lesion located on the left posterolateral side of the vesica with a $20 \mathrm{~mm}$ diameter and diverticular contrast filling excess was revealed in the CT scan. There was also a high-density tortuous lesion elongated up to the left seminal vesicle at the distal part of the left ureter. Pelvic magnetic resonance imaging (MRI) was obtained for a better analysis of these incidentally discovered structures. MRI showed that the left ureterovesical junction could not be seen because the distal portion of the left ureter ended inside of an almost $25 \times 15 \mathrm{~mm}$ solid lesion, which was located next to the left seminal vesicle.
This lesion was not filling up with contrast in the T2 phase images (Figure 1). Also, the cystic dilatation in the distal portion of the left ureter had intermediate signals in the T2 phase and high signals in T1 phase images (Figure 2). The final diagnosis was ectopic distal ureter ending in the seminal vesicle cyst's wall and ipsilateral renal agenesis. The patient was discharged without any complications and the clinical follow up was uneventful.

\section{DISCUSSION}

Congenital seminal vesicle disorders are usually associated with ipsilateral urinary duct anomalies stemming from the same embryonic structure. Ectopic ureter usually presents asymptomatically in males, therefore it is less frequent in males than in females (ratio 1:2.9). The ectopic region in men is often found in the seminal vesicle (37\%) or posterior urethra (33\%). Renal anomalies such as renal agenesis and dysgenesis are observed in $58 \%$ of cases of ectopic ureter $^{2}$. Approximately two-thirds of seminal vesicle
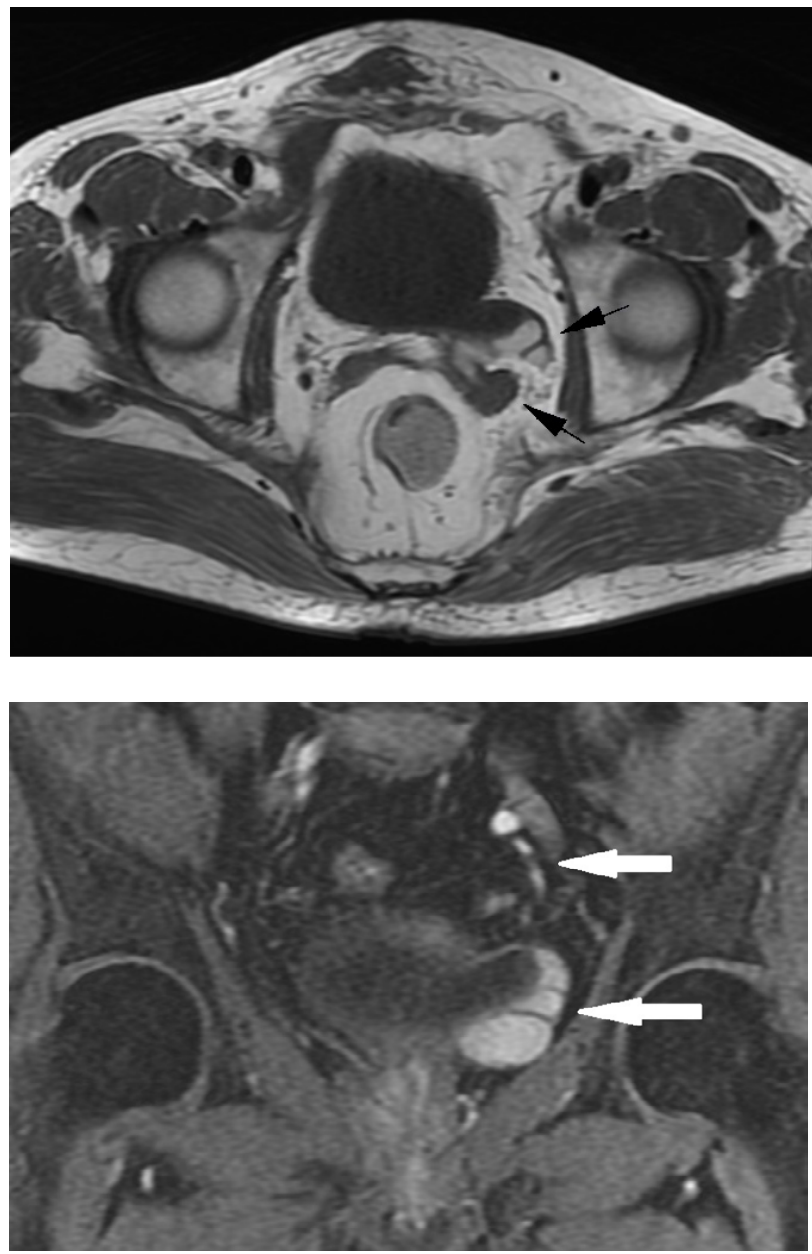

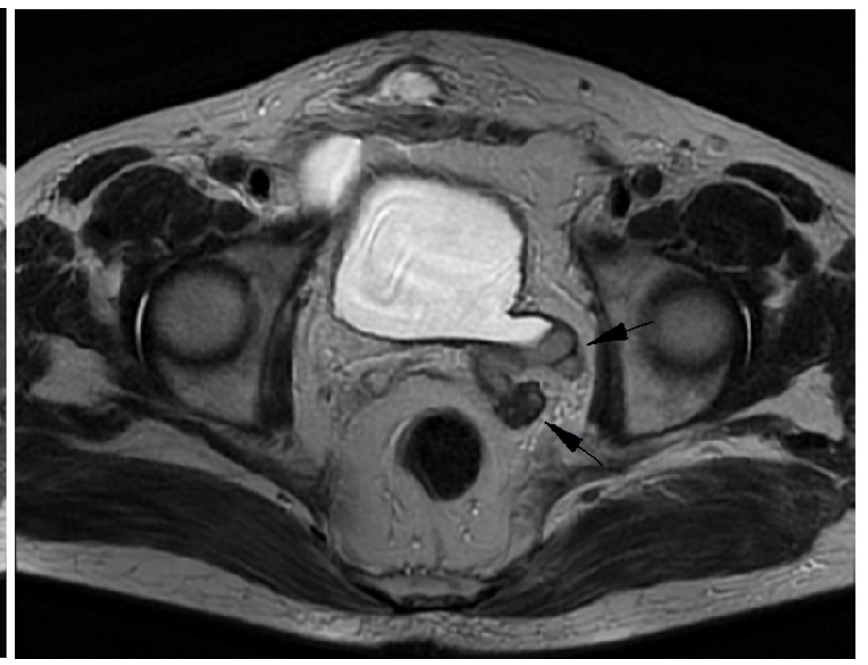

FIGURE 1.

FIGURE 2. 
cysts are associated with ipsilateral renal agenesis ${ }^{3}$. In this patient, the left distal ureter ended inside of the left seminal vesicle with a cystic dilatation. In the literature, many cases have been reported as Zinner's Syndrome with urinary and genital anomalies. Van den Ouden et al. ${ }^{4}$ analyzed 52 patients with Zinner's Syndrome and found the most common symptoms were dysuria (37\%), frequency (33\%), perineal pain (29\%), epididymitis (27\%), pain following ejaculation (21\%), and scrotal pain (13\%). Also in this study, infertility was found in 9 patients (17\%). In our case, renal agenesis was known in the patient's medical history, and the ectopic ureter and seminal vesicle cyst were incidentally revealed on the CT scan performed for the seroma. The patient was asymptomatic for years and had no fertility problems. In patients with renal agenesis, Zinner's Syndrome and ectopic ureter anomaly must be considered as a differential diagnosis. Endorectal ultrasonography, abdominopelvic CT scans, and Pelvic MRI can be used as diagnostic methods.

Uder et al. ${ }^{5}$ reported 7 patients with seminal vesicle cysts associated with ipsilateral renal agenesis, and 5 of them were followed up for a mean period of 52 months (26-119 months, mean 52 months). Only one patient was defined as symptomatic with significant enlargement of the cyst causing compression of the bladder 10 years after the primary diagnosis. Another 4 patients were totally asymptomatic. Therefore, regular clinical follow-up was recommended for asymptomatic cases. In the literature, transurethral versus transrectal approaches and laparoscopic versus open surgery techniques were identified for symptomatic patients. It is observed that laparoscopic approaches provide a minimally invasive surgical treatment and less morbidity ${ }^{6}$.

Malignancies of the ectopic ureter are rare in men and their differential diagnosis is difficult. In literature, malignancies related to ectopic ureter or seminal vesicle cysts are reported rarely. Narita et al. ${ }^{2}$ reported a case in which left nephroureterectomy with total prostatectomy was performed due to transitional cell carcinoma of an ectopic ureter. Kim et al. ${ }^{7}$ presented a case of squamous cell carcinoma due to the seminal vesicle cyst in a patient with Zinner's Syndrome. Okada et al. ${ }^{8}$ reported a case of papillary adenocarcinoma due to ipsilateral renal agenesis associated with seminal vesicle cyst but did not describe an ectopic ureter. Also, Lee et al. ${ }^{9}$ reported a case of mucinous adenocarcinoma present in a seminal vesicle cyst.
Jaidane et al. ${ }^{10}$ reported an adenocarcinoma of a ureter draining a dysplastic pelvic kidney and inserted in the cervix of a bicornuate uterus. Nakai et al. ${ }^{11}$ performed total prostatectomy and ureterectomy to a case due to prostate cancer and left ectopic ureter opening to the seminal vesicle with left renal agenesis. In our case, we consider that more attention should be taken to secondary malignancies that may develop in patients who receive strong and long-term immunosuppressive treatment due to kidney transplantation.

In renal transplantation surgery, after the completion of vascular anastomoses, the continuity of the urinary system is ensured by ureteroneocystostomy or native ureteroureterostomy. Advanced urinary tract imaging before the transplantation is generally not necessary if the recipient is asymptomatic. Native ureteroureterostomy is usually done using a ureteric catheter, like Double J. The use of this procedure in distal urinary tract malformations may result in anuria and graft dysfunction. Shenoy et al. ${ }^{12}$ reported a case of ureter anomaly leading to an ejaculatory canal detected after postoperative urinary leakage and hydronephrosis in a patient with VATER Syndrome who underwent renal transplantation and performed ureteroureterostomy. In our patient, the kidney was transplanted to the right iliac fossa, and urinary continuity was provided with ureteroneocystostomy. Patients with chronic renal failure due to renal agenesis must be examined for intact urinary tract before renal transplantation to decrease postoperative complications and graft dysfunctions.

\section{CONCLUSION}

Seminal vesicle cysts associated with ipsilateral renal agenesis or hypoplasia are a rare malformation and are usually detected accidentally. To our knowledge, this is the first case report that describes kidney transplantation in a patient with ipsilateral renal agenesis and ectopic ureter ending in the seminal vesicle cyst. However, this malformation is not a contraindication for renal transplantation. In patients with renal agenesis, during ipsilateral urinary tract anastomosis, the possibility of ectopic ureter should be kept in mind otherwise graft loss can occur with a high morbidity rate. Furthermore, we consider that asymptomatic cases should be closely followed up for secondary malignancies caused by immunosuppressive therapy. 


\section{Authors Contributions}

Korhan Tuncer: Contributed to the concept, design, and data analysis of the manuscript; Gizem Kilinc: Contributed to the data analysis and translation of the manuscript; Cem Tugmen: Contributed to the concept, design, and supervision of the manuscript; Ismail Sert: Contributed to the translation and supervision of the manuscript; Goksever Akpinar: Contributed to the design and data analysis of the manuscript; All authors contributed to the final approval of the manuscript.

\section{RESUMO}

INTRODUÇãO: A Síndrome de Zinner é uma tríade de anomalias do ducto mesonéfrico que compreende agenesia renal unilateral, cisto da vesícula seminal e obstrução do ducto ejaculatório. Neste estudo, apresentamos um receptor de rim com ureter ectópico associado à Síndrome de Zinner e revisão da literatura.

APRESENTAÇÃO DO CASO: Homem de 59 anos com história de doença renal crônica e agenesia renal esquerda foi submetido a transplante de rim de doador falecido. Após função renal ideal, foi realizada tomografia computadorizada do abdome (TC) devido ao seroma sob incisão. O diagnóstico final foi um ureter distal ectópico que termina na parede do cisto da vesícula seminal e agenesia renal ipsilateral. O paciente recebeu alta sem complicações e o acompanhamento clínico ocorreu sem intercorrências.

DISCUSSÃO E CONCLUSÃO: Os distúrbios congênitos da vesícula seminal geralmente estão associados às anomalias do ducto urinário ipsilateral devido a uma mesma estrutura embrionária. Até onde sabemos, é o primeiro relato de caso que descreve o transplante renal em um paciente com agenesia renal ipsilateral e ureter ectópico terminado no cisto da vesícula seminal. Em pacientes com agenesia renal, durante a anastomose do trato urinário ipsilateral, deve-se ter em mente a possibilidade do ureter ectópico, caso contrário, poderá ocorrer perda do enxerto com alta taxa de morbidade.

PALAVRAS-CHAVE: transplante renal, cisto de vesícula seminal, síndrome de Zinner.

\section{REFERENCES}

1. El Mortaji H, Elatiqi K, El Hammaoui H, Alj S, Fettouh A, Lakmichi A, et al. Zinner's syndrome: a case report. Prog Urol. 2018;28(10):464-5.

2. Narita S, Akao T, Tsuchiya N, Kumazawa T, Kakinuma H, Satoh $\mathrm{S}$, et al. Transitional cell carcinoma in an ectopic ureter. Int I Urol. 2003;10(5):276-7.

3. Slaoui A, Regragui S, Lasri A, Karmouni T, El Khader K, Koutani A, et al. Zinner's syndrome: report of two cases and review of the literature. Basic Clin Androl. 2016;26:10.

4. van den Ouden D, Blom JH, Bangma C, Spiegeleer AH. Diagnosis and management of seminal vesicle cysts associated with ipsilateral renal agenesis: a pooled analysis of 52 cases. Eur Urol. 1998;33(5):433-40.

5. Uder M, Siemer S, Gohl D, Schneider G, Kramann B, Humke U. Seminal vesicle cysts associated with ipsilateral renal agenesis. Diagnosis, and longterm clinical course. Radiologe. 1998;38(9):766-73.

6. Kord E, Zisman A, Darawsha AE, Dally N, Noh PH, Neheman A. Minimally invasive approach for treatment of seminal vesicle cyst associated with ipsilateral renal agenesis. Urol Int. 2017;99(3):338-42.
7. Kim Y, Baek HW, Choi E, Moon KC. Squamous cell carcinoma of the seminal vesicle from zinner syndrome: a case report and review of literature. | Pathol Transl Med. 2015;49(1):85-8.

8. Okada Y, Tanaka H, Takeuchi H, Yoshida O. Papillary adenocarcinoma in a seminal vesicle cyst associated with ipsilateral renal agenesis: a case report. J Urol. 1992;148(5):1543-5.

9. Lee $\mathrm{BH}, \mathrm{Seo} \mathrm{JW}, \mathrm{Han} \mathrm{YH}$, Kim YH, Cha SJ. Primary mucinous adenocarcinoma of a seminal vesicle cyst associated with ectopic ureter and ipsilateral renal agenesis: a case report. Korean | Radiol. 2007;8(3):258-61.

10. Jaidane M, Slama A, Bibi M. A tumor of an ectopic ureter mimicking uterine cervix adenocarcinoma: case report and brief review. Int Urogynecol J Pelvic Floor Dysfunct. 2009;20(11):1393-5.

11. Nakai Y, Tanaka M, Yoshikawa M, Tanaka N, Hirayama A, Fujimoto K, et al. Prostate cancer and left ectopic ureter opening to seminal vesicle with left renal agenesis: a case report. Hinyokika Kiyo. 2009;55(1):47-50.

12. Shenoy S, Hovsepian D, Brennan DC, Hudson MA, Howard TK, Flye MW. Anomalous ureteral insertion in VATER syndrome complicating renal transplantation. Clin Transplant. 1995;9(2):125-8. 